\author{
Anna Szymanik-KostrzeWSKa \\ Uniwersytet Kazimierza Wielkiego w Bydgoszczy \\ Instytut Psychologii \\ Katedra Psychologii Rozwoju Człowieka \\ 85-867 Bydgoszcz, ul. L. Staffa 1 \\ e-mail: alex.shilou@gmail.com
}

\title{
GRY NARRACYJNE W DIAGNOZIE I TERAPII PSYCHOLOGICZNEJ. MOŻLIWOŚCI I OGRANICZENIA W STOSOWANIU*
}

\begin{abstract}
Abstrakt. Artykuł porusza problematykę wykorzystania gier narracyjnych na użytek psychologii. Ujmuje gry narracyjne jako gry projekcyjne, pozwalające dotrzeć do ukrytych potrzeb i motywów graczy poprzez wykorzystywanie świata gry, który stanowi zestaw symboli mających dla graczy osobiste znaczenie. Diagnoza graczy możliwa jest dzięki analizie charakterystyk oraz sposobów postępowania tworzonych przez nich postaci. Terapia przy użyciu gier narracyjnych pozwala na wspomaganie leczenia niektórych zaburzeń psychicznych (jak fobia czy depresja), rozwijanie kompetencji społecznych, a zatem naukę radzenie sobie z przykrymi emocjami i kształtowanie sposobów myślenia. Przeciwwskazania do wykorzystywania gier narracyjnych w diagnozie i terapii stanowią zaburzenia psychotyczne i osobowościowe, deficyty intelektualne i nieumiejętność oddzielenia $J a$ od Ja postaci.
\end{abstract}

Słowa kluczowe: gry narracyjne, diagnoza psychologiczna, terapia psychologiczna.

\section{WSTĘP}

Gry narracyjne, będące rodzajem gier fabularnych (ang. Role Playing Games - RPG), stanowią specyficzną formę rozrywki, przeznaczoną dla osób obdarzonych wyobraźnią. Skierowane są do ludzi charakteryzujących się pewną dojrzałością, zarówno emocjonalną, jak i intelektualną. Wymagają kreatywności, a także cierpliwości i dysponowania czasem. Zasadniczą różnicę pomiędzy grami narracyjnymi a innymi rodzajami gier stanowi sposób rozgrywki - odbywa się ona

* Składam podziękowania prof. dr hab. Januszowi Trempale (UKW) za konsultacje, mgr Aleksandrze Borowskiej (UMK) za tłumaczenie streszczenia na język angielski oraz mgr Małgorzacie Racławskiej (niegdyś Straż) i mgr Mikołajowi Racławskiemu - za udostępnione informacje i dyskusję. 
przede wszystkim w umysłach graczy i ma formę opowieści, której zarys przedstawia narrator (popularnie zwany GM-em, ang. Game Master, Mistrz Gry). Narrator opisuje miejsca, zdarzenia i występujące w grze postacie (tzw. postacie narratora bądź bohaterów niezależnych), odgrywa ich zachowania oraz interakcje z graczami, nakreśla sytuacje, z którymi muszą zmierzyć się gracze, w pewnej mierze decydując o ich sukcesach i porażkach. Gracze z kolei tworzą własne postacie (ang. Original Character - OC) zgodnie z zasadami danej gry, a następnie odgrywają je i decydują o podejmowanych przez nie akcjach.

Gry narracyjne nazywane są ,papierowymi”, gdyż zwykle używa się w nich papierowych Kart Postaci, na których umieszcza się statystyki postaci (ich zdolności, umiejętności i podstawowe charakterystyki). Istnieją różne systemy gier narracyjnych, opisane w podręcznikach, które zawierają informacje o rodzaju gry (fantasy, historyczna, oparta na filmie bądź książce etc.), zasadach tworzenia postaci i grania (mechanika gry) oraz o świecie, w którym gra ma miejsce (np. starożytna Japonia, świat po apokalipsie, współczesność). Przykład stanowić mogą popularne w Polsce Dungeons \& Dragons (w skrócie DnD, polskiego thumaczenia raczej się nie stosuje), Wampir: Maskarada, Dzikie Pola czy Wiedźmin: Gra Wyobraźni. Akcesoria używane do gry stanowią zwykle kostki wielościenne, odpowiadające za losowość w grze. Gracze, w zależności od statystyk swoich postaci, używają pewnej liczby kości i wykonują rzut w sytuacji deklarowania akcji, która może się nie powieść (np. gracz decyduje, że jego przeciętnie wysportowana postać chce skoczyć z dachu jednego budynku na drugi). Upraszczając - im wyższy wynik rzutu (więcej tzw. sukcesów), tym większa szansa powodzenia akcji.

Specyfikę gier narracyjnych stanowi sam sposób gry, w tzw. sesjach, trwających często po kilka godzin i składających się na opowieść. Gracze, odgrywając swoje postacie, „wcielają się" w nie - opisują ich zachowanie i wypowiadają się w pierwszej osobie. W sesji bierze zwykle udział kilku graczy i narrator. Postacie wchodzą ze sobą w różnorodne interakcje, tworzą sojusze i drużyny bądź rywalizują ze sobą, wykonując różne zadania i stawiają czoło przeciwnościom. W grach narracyjnych nie ma przegranych, gdyż o sukcesie świadczy osiągnięcie założonych przez każdego z graczy celów, a dodatkową gratyfikację stanowią punkty doświadczenia, przyznawane za odgrywanie postaci zgodne z Kartą Postaci oraz deklarowanym przez gracza charakterem bohatera (punkty pozwalają na rozwinięcie statystyk postaci).

Gry fabularne obejmują szerszy repertuar gier, także gry komputerowe, w których gracz tworzy swoją postać (awatara), a następnie kieruje jej akcjami. Rolę Mistrza Gry przejmuje w tym przypadku komputer, który odpowiada za interakcje gracza w świecie gry, za prowadzenie fabuły i przestrzeganie zasad (Szymanik, Kostrzewski, 2012). Gry komputerowe umożliwiają uczestniczenie w tej samej grze większej liczby graczy bez konieczności gromadzenia się w tym samym miejscu. Przykładami są Ultima Online bądź Neverwinter Nights. Podstawową różnicę pomiędzy ,papierowymi” a komputerowymi grami fabularnymi 
stanowi sposób interakcji graczy, którzy w przypadku sesji gry narracyjnej mają ze sobą bezpośredni kontakt, mogą obserwować swoją mimikę i zwracać uwagę na pozawerbalne charakterystyki wypowiedzi, często bardzo przydatne dla rozwoju fabuły (gracze wyrażają emocje swoich postaci, czasem wprowadzają elementy dramy, odgrywając zachowania postaci). Gra komputerowa pozwala zwykle na obserwowanie jedynie zachowania awatara, a tym samym ograniczone wnioskowanie o intencjach gracza i emocjach jego postaci.

Dotąd wiele publikacji poświęcono badaniom osób angażujących się w gry narracyjne (fabularne) (zob. Chmielnicka-Kuter, 2004), wykazując między innymi brak różnic pomiędzy graczami a nie-graczami w zakresie stabilności emocjonalnej (Simon, 1987, 1998), porównywalne bądź niższe wskaźniki Neurotyczności i Psychotyczności u graczy (Abyeta, Forest, 1991; Carter, Lester, 1998), brak u graczy symptomów depresyjnych i tendencji samobójczych (Carter, Lester, 1998) oraz podobny poziom poczucia wyobcowania graczy i osób nie angażujących się w gry narracyjne (DeRenard, Kline, 1990). Gry narracyjne zostały również uznane za skuteczne narzędzie w edukacji (zob. Szeja, 2004; Szymanik, Kostrzewski, 2012). Jednakże nieliczne artykuły wskazują na przydatność gier narracyjnych w terapii psychologicznej (Blackmon, 1994; Hughes, 1988; Panak, Drzewiecka, 2005), a zwłaszcza w diagnozie (Chmielnicka-Kuter, 2005). W prezentowanym opracowaniu podjęto próbę opisania gier narracyjnych w kontekście przydatności do diagnozy psychologicznej graczy oraz do psychoterapii, uwzględniając możliwości i ograniczenia tej metody.

\section{GRY NARRACYJNE JAKO NARZĘDZIE DIAGNOZY PSYCHOLOGICZNEJ}

Diagnoza w psychologii jest definiowana jako ,proces aktywnego poszukiwania danych potrzebnych do podjęcia decyzji o działaniach zmierzających do zmiany aktualnego stanu (położenia) psychospołecznego ludzi" (Paluchowski, Hornowska, 2003, s. 509). Dokonuje się jej przy użyciu różnorodnych narzędzi (np. wywiadu, obserwacji, testów psychologicznych). Specyficzną formę narzędzi wykorzystywanych przez psychologów stanowią techniki projekcyjne, czyli metody badania oparte na projekcji, które nie wymagają ścisłej procedury postępowania (Stasiakiewicz, 2003). Słowo ,projekcja” w mowie potocznej oznacza „rzutowanie”. Podczas projekcji człowiek nieświadomie nadaje zewnętrznej rzeczywistości swoją treść, która koreluje z niektórymi aspektami osobowości rzutującego, np. pragnieniami czy potrzebami. Cechy osobowości, które wyrażają się w projekcji, zwykle są produktem dawnych przeżyć i doświadczeń człowieka, wywołanymi poprzez związane $\mathrm{z}$ tymi przeżyciami przedmioty i sytuacje zewnętrzne (Rembowski, 1986).

Niewątpliwą zaletą projekcji jest możliwość dotarcia do nieuświadomionych lub słabo uświadamianych potrzeb czy też cech człowieka. Możliwość taką 
stwarzają gry narracyjne, które można by wręcz nazwać grami projekcyjnymi (Szymanik, Mączyńska, 2010) w znaczeniu atrybutywnym. „Projekcja atrybutywna polega na przypisywaniu własnych motywów, uczuć i zachowań innym osobom" (Rembowski, 1986, s. 22). W podręczniku do gry Wampir: Maskarada znajdujemy następujący ogólny opis rozgrywki: „gracze przyjmują osobowości wampirów [...] i prowadzą te postacie przez świat faktycznie identyczny jak nasz" (Rein-Hagen i in., 2002, s. 22). Taki sposób gry umożliwia swobodne rzutowanie przez gracza swoich cech osobowości na postać, wybieranie ważnych dla siebie celów i symboliczne zaspokajanie własnych potrzeb w trakcie gry. Tym samym psycholog jest w stanie przeprowadzić diagnozę gracza w oparciu o charakterystyki i zachowanie jego postaci.

\subsection{Diagnoza graczy na podstawie charakterystyk postaci}

Diagnozę gracza na podstawie utworzonej przez niego postaci można przeprowadzić przy założeniu, że system gry pozwala na umiarkowaną dowolność przy jej kreowaniu. Istnieją systemy, w których niemal wszystkie charakterystyki postaci są losowane przez rzuty kośćmi, jednakże w sytuacji, gdy gracz ma możliwość samodzielnego jej tworzenia, istotne do diagnozy cech czy problemów w funkcjonowaniu człowieka mogą się okazać cechy osobowości przypisywane postaci, wymyślona dla niej historia życia, a nawet wygląd fizyczny.

Na znaczenie wyglądu postaci wskazują wyniki badań przeprowadzonych do celów marketingowych, obejmujących 75 użytkowników gry Second Life ze stanów Zjednoczonych, Francji i Kanady (Bélisle, Bodur, 2010). Wszyscy gracze ukończyli 18 lat, a ich średnia wieku była stosunkowo wysoka - wynosiła 33 lata. $56 \%$ próby stanowiły kobiety. Badani wypełniali kwestionariusze oparte na teorii Pięcioczynnikowego Modelu Osobowości w odniesieniu do cech swoich i swoich postaci, a także udostępniali swój awatar, który podlegał ocenie pod kątem 145 wizualnych charakterystyk. Bélisle i Bodur (2010) na podstawie wyników wysunęli wniosek, że cechy wyglądu awatarów mogą stanowić przydatne wskazówki do wnioskowania o osobowości i stylu życia graczy. Cechy fizyczne awatarów (jak kolor włosów czy sposób ubierania się) korelowały z przypisywanymi im cechami, takimi jak ekstrawersja czy ugodowość. Co ciekawe, nie zawsze miały one przełożenie na cechy gracza. Przykładowo niektórzy gracze celowo prezentowali siebie poprzez awatary jako bardziej sumiennych i ugodowych.

$Z$ punktu widzenia diagnozy potrzeb człowieka, zwłaszcza nie w pełni uświadamianych, taka rozbieżność stanowić może ważną informację. Sposób wnioskowania na podstawie postaci tworzonych do wspomnianej gry fabularnej może być wykorzystany w przypadku narracyjnych gier ,papierowych”. Należy jednak pamiętać, że postać gracza stanowi często stanowi coś więcej niż wyostrzone odbicie jego cech. 
John Hughes (1988) zakłada, że gracz, tworząc postać, kreuje swoje symboliczne $J a$. Postać jest zarówno graczem (symbolem gracza) - estetycznym (aesthetic symbol), czyli wytworem kreatywności gracza (twórca świadomie nie nadaje jej obmyślonych cech osobowości) bądź osobistym (personal symbol). Postać jako symbol osobisty ,zawiera" w sobie trzy kategorie symboli - wzmacniające (exaggerating), poznawcze (cognitive) i kompensacyjne (compensatic).

Postać jako symbol wzmacniający stanowi złożenie cech osobowościowych, które gracz uważa, że posiada i które chce jednocześnie rozwijać. Postać będąca symbolem poznawczym jest stworzona przez gracza na bazie cech, których, jak sądzi, sam nie posiada, by „doświadczyć bycia kimś innym”. Postaci jako symbolowi kompensacyjnemu gracz nadaje te cechy, których uważa, że nie posiada, ale chciałby posiadać (cechy te stanowią zwykle element $J a$ idealnego, rzadziej powinnościowego).

Wśród niepisanych zasad dla początkujących graczy, angażujących się w gry narracyjne, możemy znaleźć następujące zalecenia (m.in. Szymanik, Mączyńska, 2010):

- stwórz taką postać, żeby było ci przyjemnie ją odgrywać;

- nie twórz postaci skrajnie innej, niż ty, bo nie będziesz w stanie jej odegrać;

- nie twórz postaci idealnie takiej samej, jak ty, bo za bardzo będziesz brał do siebie to, co się dzieje w grze.

Kierując się tymi zasadami, większość graczy najprawdopodobniej tworzy postać będącą symbolem pośrednim pomiędzy wzmacniającym, poznawczym a kompensacyjnym. Prowadząc diagnozę, warto więc dowiedzieć się od gracza, jakie swoje cechy nadał postaci, a jakich cech postaci on sam nie prezentuje. Zasadna wydaje się także dyskusja na temat motywacji do wyboru charakterystyk postaci, jednakże nie tylko obejmujących cechy osobowości. Postać gracza bowiem może być pomocna nie tylko do wnioskowania o jego chęci do nabywania i rozwijania cech czy ciekawości poznawczej.

W 2007 r. opublikowano interesujące wyniki badań nad preferencjami graczy w stosunku do wyboru określonego typu postaci (Hsu i in., 2007). Przebadano ponad tysiąc nastolatków (średnia wieku 19 lat), których skategoryzowano i przyporządkowano do pięciu grup osobowości: przeciętnych (average type), nieprzychylnych (black-list type), spokojnych (calm type), bezpośrednich (direct type) i ekscentrycznych (eccentric type). Następnie na podstawie cech wyróżniono trzy typy odgrywanych postaci: herosów (Warrior), liderów-wizjonerów (Visionary Leader) i świętych (Saint). Chociaż nie potwierdzono bezpośredniego związku osobowości graczy z preferowaniem typu odgrywanych postaci, zaobserwowano, że tendencje do wyboru Herosów mają osoby o dwóch stosunkowo wysokich wskaźnikach poznania społecznego - podobieństwie (similiarity) i zażyłości ( $f a-$ miliarity) (Hsu i in., 2007). Autorzy artykułu założyli, że preferencje graczy do wyboru Herosów wynikały z ich spostrzeganego podobieństwa do postaci. Ponadto zasugerowali, że im bardziej gracze zżywają się z rolą swojej heroicznej 
postaci, tym większe mają tendencje do jej wyboru. Stopień zżycia czy też zlania się z postacią zwany jest immersyjnością czy też immersją, odnoszoną m.in. do stopnia identyfikacji gracza z postacią w grze (zob. Prajzner, 2009). Można założyć, że wraz ze stopniem immersji gracza i postaci wzrasta siła rzutowanych na postać cech, pragnień, motywacji i potrzeb gracza.

W Polsce interesującą diagnozę graczy przeprowadziła Chmielnicka-Kuter (2005). Skonfrontowała ona postacie 34 graczy obu płci (6 kobiet, 28 mężczyzn, w wieku 16-28 lat) z samymi graczami. Gracze formułowali wartościowania wyrażające swoje ustosunkowanie wobec postaci, a następnie wcielali się w swoje postacie i oceniali siebie z ich perspektywy. Wyniki badań pozwoliły przyjąć, że relacja gracz-bohater gry była dla graczy okazją do doświadczania raczej uczuć pozytywnych niż negatywnych, natomiast relacja odwrotna wiązała się bardziej z uczuciami ambiwalentnymi. Wśród treściowych aspektów wartościowań znalazły się przykłady idealizowania postaci, skupiania osobistych ideałów gracza, identyfikacji z postacią jako źródła umacniania siebie, ale także definiowania granic pomiędzy Ja graczy i postaci (tożsamość-w-różnicy). Odniesienia postaci do graczy obejmowały m.in. relacje współpracy, dominację jednej ze stron, ale także odniesienia krytyczne i zderzenia przeciwieństw.

Chmielnicka-Kuter (2005) przyjmuje, że jednym z uzasadnień użyteczności diagnozy jest możliwość wykorzystania postaci do twórczej eksploracji i zmian wybranych, ważnych aspektów tożsamości gracza. Bazując na wynikach jej badań można przyjąć, że postacie graczy nie stanowią w pełni ich odzwierciedleń, ale też nie są ich zupełnymi przeciwieństwami. Określenie, w jakim stopniu postać jest zbliżona do $J a$ gracza, w jakim zaś jest wytworem jego kreatywności, opartym na nie- $J a$, jest dla diagnosty rzeczą trudną i wymagającą wnikliwości. Nie należy pokładać pełnego zaufania w diagnozie opartej jedynie na opisie postaci przez gracza, gdyż - jak twierdzi Hughes (1988) - gracz operuje cechami, które uważa, że posiada bądź nie. Opis postaci jest ściśle zależny od świadomości gracza i jego oceny. Pełniejszy obraz daje obserwacja gracza i zachowania jego postaci podczas sesji.

\subsection{Diagnoza graczy na podstawie zachowania się postaci w trakcie gry}

Rozbieżność między deklarowanymi a rzeczywistymi cechami postaci (gracza) zilustruję przykładem sesji gry Wampir: Maskarada, w której uczestniczyłam. W pewnym momencie wszystkie postacie znalazły się w obiektywnie trudnej sytuacji - ścigane, w miejscu pozornie bez ucieczki (na dachu wysokiego budyn$\mathrm{ku}$ ), w dodatku $\mathrm{z}$ ważną dla graczy postacią narratora, poważnie rannego podczas walki z przeciwnikami (z człowiekiem o imieniu David). W chwili, gdy David stracił przytomność na skutek utraty krwi (sytuacja była odgrywana w czasie 
rzeczywistym, gracze mieli zaledwie sekundy na podjęcie akcji), reakcje opisanych graczy były zaskakujące. Postać kobiety o naturze opiekuna, obdarzona przez jej twórczynię takimi cechami, jak empatia, opiekuńczość i chęć niesienia pomocy, zignorowała utratę przytomności przez Davida i podeszła do krawędzi dachu, żeby sprawdzić, czy odczuwa lęk wysokości (na podstawie tego chciała wnioskować, czy to sen, czy rzeczywistość i podejmować dalszą akcję). Z kolei mężczyzna, który z założenia był wojownikiem i zabójcą, nie posiadał cech opiekuńczych, podjął natychmiast decyzję o udzieleniu mu pomocy, w efekcie ratując człowiekowi życie.

W terminologii gry tego typu zachowania określane są ,łamaniem koncepcji postaci" - zgodnie z deklarowanym opisem to kobieta powinna udzielić człowiekowi natychmiastowej pomocy, a mężczyzna powinien dać mu umrzeć. W rzeczywistości była to jedna z sytuacji (stresująca, wymagająca podejmowania szybkich decyzji, o bardzo ograniczonym czasie przeznaczonym na obmyślenie, jak odegrać postać), w których ujawniły się cechy graczy, a nie postaci. Twórczyni postaci kobiety w sytuacji stresowej za priorytet przyjęła poszukiwanie wyjścia z sytuacji, czyli ujawniła najczęstszą reakcję na stres - walkę bądź ucieczkę (fight-or-flight response). Gracz (kobieta) prowadzący postać mężczyzny z kolei zareagował troską wobec osoby potrzebującej pomocy, prezentując bardziej kobiecą reakcję na stres, polegającą na podejmowaniu opieki (tend-and-befriend response, czyli opieka bądź zaprzyjaźnianie się) (zob. Taylor $\mathrm{i}$ in., 2000).

Obserwowanie gracza podczas gry może dostarczyć wiele informacji na temat nie tylko jego reakcji, ale i motywacji. Richard Bartle (1996) dokonał podziału graczy w komputerowe gry fabularne, który można przełożyć na świat „papierowych" gier narracyjnych. Wyróżnił on cztery kategorie:

- okrywców (Explorers), czyli graczy nastawionych na odkrywanie możliwości świata gry i czerpanie satysfakcji z tego, co mogą przeżyć, czego mogą doświadczyć. Tacy gracze, angażując się w gry narracyjne, pozbawiają się możliwości doświadczania wrażeń wizualnych, ale uzyskują możliwość bezpośredniej interakcji z graczami odgrywającymi inne postacie. U podstaw tego typu gry można upatrywać ciekawości poznawczej i potrzeby doznań u gracza.

- poszukiwaczy towarzystwa (Socializers), czyli osoby nastawione na kontakt z innymi graczami. Gry narracyjne dają im bardzo duże możliwości, gdyż niemal wszystkie sesje zakładają uczestnictwo przynajmniej dwóch graczy i jakiegoś rodzaju współpracę. Tego typu gra zwana jest potocznie „grą na relacje” i może świadczyć o potrzebie kontaktów społecznych u gracza.

- wyczynowców (Achievers), czyli graczy pragnących podwyższać statystyki swoich postaci i osiągać coraz to nowe umiejętności. W grach narracyjnych osiągnięcia zależą od wyobraźni, kreatywności, innowacyjności w myśleniu, ale jednocześnie od odgrywania postaci zgodnie z założoną koncepcją. U graczy tych można postulować istnienie silnej potrzeby osiągnięć i gratyfikacji. 
- zabójców (Killers), do których zaliczamy osoby nastawione na rywalizację i walkę z innymi graczami, czerpiące satysfakcję z utrudniania rozgrywki innym i ,złej sławy”. Tego typu motywacje w grach narracyjnych są niekorzystne, gdyż nie tylko odbierają przyjemność z gry pozostałym graczom, ale też często prowadzą do sprzeciwu narratora w postaci określonych konsekwencji, nieprzyjemnych dla Zabójcy (np. bardzo silny przeciwnik, który w starciu zabija postać gracza). Niewykluczone, że gracze tego typu doznają silnego stresu i odczuwają wrogość, którą starają się rozładować poprzez agresywny sposób gry. Możliwe również, że poprzez grę postacią zdolną do czynienia krzywdy kompensują spostrzeganą u siebie słabość, brak umiejętności bądź poczucie niższości. Sukces w zabijaniu i niszczeniu może stanowić dla nich sposób podwyższania samooceny i nastroju.

Gracze mogą w rzeczywistości należeć do więcej niż jednej kategorii. Na podstawie ich zachowania na sesji można jednak wnioskować o pewnych, charakterystycznych dla typów graczy potrzebach, motywacjach czy trudnościach w funkcjonowaniu. Mogą one - w większym lub mniejszym stopniu - przekładać się na ich życie codzienne.

Diagnoza gracza, zarówno na podstawie charakterystyk jego postaci, jak i poprzez obserwację jego gry, ma oczywiście swoje ograniczenia. Przede wszystkim jest czasochłonna i pracochłonna. Karta Postaci może zawierać nawet kilkaset różnorodnych cech postaci - część z nich jest przedstawiona za pomocą konkretnych specyfikacji (wygląd, inteligencja, zdolności społeczne, umiejętności, rola), inne wynikają z tych specyfikacji (np. rola „wojownik” wiąże się z takimi cechami, jak odwaga, szlachetność czy waleczność), niektóre natomiast zostają wplecione w historię życia postaci. Sesja gry z kolei trwa przynajmniej kilka godzin, a żeby zaobserwować różnorodność zachowań postaci, należałoby uczestniczyć w odgrywaniu kilku różnych opowieści (np. zakładającej bezpośrednią konfrontację z wrogami i częste walki; nastawionej na myślenie, odkrywanie i rozwiązywanie zagadek; wymagającej ścisłej współpracy i zaufania; opartej na rywalizacji, współzawodnictwie o zasoby; zawierającej motywy zemsty). Od diagnosty wymagana jest też przynajmniej podstawowa znajomość systemu i mechaniki gry, gdyż zachowania graczy i charakterystyki ich postaci są z nimi bezpośrednio związane. Ponadto diagnoza gracza powinna być uzupełniona innymi metodami, przede wszystkim wywiadem, który zawierałby bezpośrednie pytania na temat kreacji postaci oraz jej akcji na sesji. Może się bowiem okazać, że niektóre specyfikacje i sposoby postępowania są narzucone przez rodzaj czy sposób gry lub narrator preferuje określone rozwiązania, które gracze nieświadomie lub świadomie stosują.

Diagnoza gracza przy wykorzystaniu jego postaci jest bez wątpienia trudna, jednakże daje dostęp do nieuświadomionych potrzeb, emocji, motywów i cech człowieka, o których istnieniu trudno byłoby wnioskować na podstawie metod opartych na samowiedzy i deklaracjach badanego. Bardziej dyskusyjną kwestią jest jednakże terapia przy wykorzystaniu gier narracyjnych. 


\section{STOSOWANIE GIER NARRACYJNYCH W TERAPII PSYCHOLOGICZNEJ}

Terapia psychologiczna (psychoterapia) współcześnie jest definiowana na różne sposoby. Szeroko rozumiana oznacza zamierzone i planowane działania, prowadzone przez odpowiednio wyszkolonych specjalistów wobec osób o zaburzeniach psychicznych, zaburzeniach zachowania czy problemach zdrowotnych, mające na celu zmianę ich wzorów zachowania, struktur lub procesów intrapsychicznych. Działania psychologiczne w procesie terapii są ukierunkowane na leczenie zaburzeń, zmianę lub modyfikację zachowań, schematów poznawczych i emocji ludzi, ale także na korektę ich postaw wobec pojawiających się w życiu problemów i trudności (zob. Cierpiałkowska, Czabała, 2007).

Gry narracyjne mogą być wykorzystywane we wszystkich wymienionych oddziaływaniach, chociaż opisane w literaturze przypadki ich stosowania są nieliczne. Przykład terapii połączonej z diagnozą - przy wykorzystaniu postaci z gry narracyjnej - 27-letniej Malori, cierpiącej na depresję, przytoczył Hughes (1988). Malori, dzięki odgrywaniu postaci Jacka, nie tylko zorientowała się, co może być przyczyną jej zaburzeń nastroju, lecz także znalazła sposób ich skutecznej eliminacji (w polskich opracowaniach piszą o jej przypadku Chmielnicka-Kuter, 2004 oraz Panak, Drzewiecka, 2005). Z kolei Blackmon (1994) opisał przypadek 19-letniego Freda, pacjenta o osobowości schizoidalnej, któremu gra pomogła dotrzeć do nieuświadamianych i nieakceptowanych emocji, stanowiących jedną z głównych przyczyn trudności w codziennym funkcjonowaniu (w polskim opracowaniu w: Chmielnicka-Kuter, 2004).

Panak i Drzewiecka (2005) opublikowali historię 22-letniej Anny, która cierpiała na specyficzny rodzaj fobii - przed wilkołakami - generalizowanej na tematykę wilków, ciemny las, księżyc w pełni. Anna zdecydowała się na wykorzystanie gry w systemie Wilkotak: Apokalipsa jako jednej z form terapii fobii - terapii implozywnej, polegającej na konfrontacji ze źródłem lęku w sytuacji bezpiecznej. Po sześciu miesiącach gry objawy fobii u Anny ustąpiły niemal zupełnie (szerzej: Panak, Drzewiecka, 2005, s. 23-24). Analogiczny przypadek w wywiadzie zrelacjonowała Straż (za: Szymanik, Kostrzewski, 2012) - dzięki grze w gry narracyjne nieintencjonalnie nauczyła się opanowywać swój lęk przed ciemnością. Prowadząc postać wampira w Świecie Mroku zauważyła, że wielokrotnie powtarzana podczas sesji wizualizacja ekspozycji na bodziec lękowy (przebywanie w ciemności, poruszanie się jedynie w nocy) przyczyniła się do zminimalizowania u niej objawów fizjologicznej fobii w realnych sytuacjach.

Wykorzystanie gier narracyjnych do terapii psychologicznej zaburzeń bądź trudności w funkcjonowaniu jest zbliżone do techniki terapeutycznej dramy (zob. Emunah, 1994; Landy, 2009). Proces grania pozwala na wypróbowywanie alternatywnych sposobów funkcjonowania i ćwiczenie zachowań, które mogą następnie zostać przeniesione przez gracza do realnego świata. Gry stają się tym samym pomocne $\mathrm{w}$ rozwiązywaniu kryzysów, rozumianych jako trudne sytuacje 
życiowe, w których brak człowiekowi umiejętności i/lub zasobów, koniecznych do sprostania trudnościom. Przeniesienie takich sytuacji w świat gry, albo w postaci symbolicznej, albo jako dokładne odzwierciedlenie, pomaga spojrzeć na problem z innej perspektywy, zdystansować się, poszukać zasobów bądź rozwinąć potrzebne umiejętności.

Gry narracyjne, podobnie jak komputerowe (zob. Russoniello i in., 2009), mogą być pomocne także $w$ radzeniu sobie z przykrymi emocjami. Thayer $\mathrm{i}$ in. (1994) w badaniach nad preferowanymi przez ludzi sposobami poprawiania odczuwanego nastroju wykazali, że kobiety stosowały raczej metody pasywne w postaci czynności takich jak jedzenie słodyczy czy spanie, a także gratyfikowanie własnych potrzeb (np. poprzez zakup biżuterii czy strojów) i poszukiwanie wsparcia społecznego. Mężczyźni z kolei częściej niż kobiety poszukiwali aktywności przyjemnych i angażujących uwagę. Gra jako rozrywka stanowi aktywną czynność podwyższającą nastrój, angażuje uwagę i wymaga zaangażowania, a więc w tym sensie bardziej odpowiada mężczyznom. Daje jednak duże możliwości symbolicznej gratyfikacji potrzeb (zaspokajane są zarówno potrzeby postaci poprzez osiąganie celów, jak i niektóre potrzeby gracza poprzez werbalne gratyfikacje uzyskiwane od innych graczy i narratora po odegraniu postacią udanej akcji) oraz otrzymania wsparcia społecznego od innych postaci.

Nie sposób pominąć użyteczności gier narracyjnych do nauki, kształtowania i doskonalenia kompetencji społecznych. Z założenia są one grami angażującymi więcej niż jednego gracza, a więc „wymuszają” interakcje społeczne. Na sesjach gracze mogą rozwijać umiejętności spostrzegania i rozumienia ludzi, pomagania i wywierania wpływu, rozwiązywania problemów i konfliktów (Mellibruda, 2003), okazywania uczuć i empatii, organizowania grup, negocjowania rozwiązań, nawiązywania stosunków osobistych (Goleman, 1997), słuchania, zadawania pytań, konkretyzowania, składania propozycji czy udzielania rad (Acland, 2000). Profesor psychologii i terapeuta Bassam Aouil czynnie wykorzystuje gry narracyjne w pracy terapeutycznej z małżeństwami jako jeden ze sposobów komunikacji pomocnej w rozwiązywaniu konfliktów interpersonalnych1.

Urlich Betz (2011) podkreśla, że gry narracyjne kształtują pewne sposoby myślenia i rozumowania, które są w dużej mierze korzystne dla rozwoju człowieka. Uczą, że człowiek do osiągnięcia sukcesu potrzebuje innych ludzi (drużyny), którzy powinni być różnorodni - tak, by talenty uzupełniały się. Równocześnie osoby w drużynie powinny zgadzać się w fundamentalnych założeniach, dzielić takie same wartości i wizję. Praca może być zabawą, jeśli zachowuje się w niej umiar i nie popada w pracoholizm, a wraz z rozwojem coraz więcej umiemy i coraz więcej rzeczy staje się dla nas możliwych. Gry narracyjne pozwalają rozwijać postawę prospołeczną, nastawioną na współpracę i zrozumienie, realistyczny

${ }^{1}$ Informacja osobista, udzielona na V Interdyscyplinarnej Konferencji Doktorantów i Młodych Naukowców, Bydgoszcz, 23-25 kwietnia 2015 r.). 
optymizm wobec wyzwań oraz autonomię w kształtowaniu siebie połączoną z wiarą we własne możliwości, wciąż zwiększające się. Dla osób wycofanych, nastawionych na rywalizację, niechętnych wobec aktywności i życiowo biernych gra narracyjna może stać się okazją do konstruktywnej zmiany sposobu myślenia, który może zostać zgeneralizowany poza środowisko gry.

Przytoczone przykłady i możliwości nie stanowią wskazań sensu stricto do stosowania gier narracyjnych w terapii psychologicznej, a raczej podkreślenie potencjalnych możliwości. Chociaż gry narracyjne mogą być użyteczne jako technika terapeutyczna, należy mieć świadomość ograniczeń w tym zakresie. Przede wszystkim terapia w oparciu o nie wymaga znacznych umiejętności osoby ją prowadzącej, a także wiedzy w zakresie systemów i mechaniki poszczególnych rodzajów gier. Ponadto terapia taka nie jest przeznaczona dla każdego. Jest czasochłonna, a jednym z koniecznych warunków jest zaangażowanie gracza i motywacja do pracy nad swoją postacią. Ponadto gry narracyjne wydają się niewskazane dla osób z deficytami poznawczymi, gdyż rozgrywka może się okazać dla nich zbyt obciążająca lub za trudna. Nie zaleca się również stosowania gier narracyjnych u osób z niektórymi zaburzeniami psychicznymi i zaburzeniami osobowości - takimi, które utrudniają lub uniemożliwiają oddzielenie świata gry od świata rzeczywistego (Ascherman, 1993). Należy jednak podkreślić, że sytuacje pełnej identyfikacji gracza z postacią zdarzają się także u zdrowych osób w sytuacjach o osobistym dla gracza znaczeniu. W grze traktowanej jedynie jako rozrywka mogą być problemowe i prowadzić do konfliktów między graczami bądź między graczem i narratorem. $Z$ punktu widzenia psychologa wydają się jednak wartościowe, gdyż pozwalają dotrzeć do nie w pełni uświadomionych konfliktów i problemów.

\section{ZAKOŃCZENIE}

Gry narracyjne zgodnie ze swym przeznaczeniem stanowią formę intelektualnej rozrywki, atrakcyjnej zarówno dla młodzieży, jak i dla dorosłych. J. Hughes (1988) na podstawie wywiadów sformułował cztery powody, dla których mogą być uznane za wartościowe: zapewniają ucieczkę od presji społecznej, pomagają zwiększać poczucie samokontroli i własnej wartości, pozwalają rozwijać umiejętności społeczne i mają walory edukacyjne (zob. Szeja, 2004). Można dodać, że są również okazją do aktywnego kontaktu z osobami o podobnych zainteresowaniach, a więc do nawiązywania znajomości i uzyskiwania wsparcia.

Pomysł wykorzystania gier narracyjnych $\mathrm{w}$ diagnozie i terapii nie jest nowością, a jego popularność wzrasta. Trudność ich stosowania w diagnozie psychologicznej stanowi przede wszystkim brak standaryzowanych narzędzi, opartych na konkretnych systemach gry bądź na sposobach tworzenia postaci. Jest to wciąż swobodna technika diagnozy, której rzetelność jest dyskusyjna. Jeśli natomiast 
chodzi o terapię psychologiczną, główny problem stanowi brak odgórnych założeń terapeutycznych i wytycznych do jej stosowania. Sposób prowadzenia terapii jest bardzo zindywidualizowany i dopasowany do jednostki, cele terapii ustalane są również indywidualnie, w zależności od potrzeb osoby, która zostaje jej poddana. Ponadto brakuje badań na szerszą skalę, który pozwoliłyby wnioskować o skuteczności takiej terapii.

Zdecydowana większość sesji gier narracyjnych stanowi obecnie przede wszystkim rozrywkę, prowadzą je osoby pozbawione specjalistycznej wiedzy psychologicznej, ich pomoc ma charakter koleżeński, nie terapeutyczny, a ich świadomość konsekwencji jest ograniczona. Jednakże wzrastająca powszechność gier narracyjnych zachęca do stosowania ich nie tylko jako formy rozrywki czy nauki (zob. Szeja, 2004), lecz także w terapii psychologicznej, która wykorzystuje projekcję jako podstawę do diagnozy, a wyobrażony świat gry - jako zestaw symboli, mających dla gracza osobiste znaczenie.

\section{BIBLIOGRAFIA}

Abyeta S., Forest J. (1991). Relationship of role-playing games to self-reported criminal behaviour. Psychological Reports, 69 (3), December, 1187-1192.

Acland A. F. (2000). Doskonałe umiejętności interpersonalne: wszystko, czego potrzebujesz, aby udało ci się za pierwszym razem, tłum. M. Makowska. Poznań: Dom Wydawniczy REBIS.

Ascherman L. I. (1993). The impact of unstructured games of fantasy and role playing on an inpatient unit for adolescents. International Journal of Group Psychotherapy, 43 (3), 335-344.

Bartle R. (1996). Hearts, clubs, diamonds, spades: Players who suit MUDs, http://www.mud.co.uk/ richard/hcds.html [dostęp: 25.01.2014].

Betz U. A. K. (2011). What fantasy role-playing games can teach your children (or even you). British Journal of Educational Technology, 42 (6), E117-E121.

Bélisle J.-F., Bodur H. O. (2010). Avatars as Information: Perception of Consumers Based on Their Avatars in Virtual Worlds. Psychology and Marketing, 27 (8), 741-765.

Blackmon W. D. (1994). Dungeons and Dragons: The Use of a Fantasy Game in the Psychotherapeutic Treatment of a Young Adult. American Journal of Psychotherapy, 48 (4), 624-632.

Carter R., Lester D. (1998). Personalities of players of Dungeons and Dragons. Psychological Reports, 82, 182.

Chmielnicka-Kuter E. (2004). Gry fabularne w badaniach psychologicznych. Polskie Forum Psychologiczne, 9 (2), 124-138.

Chmielnicka-Kuter E. (2005). Wyobrażone postacie i ich autorzy: analiza wzajemnych odniesień na przykładzie zjawiska gier fabularnych. Przeglą Psychologiczny, 48 (1), 53-73.

Cierpiałkowska L., Czabała C. (2007). Psychoterapia indywidualna i grupowa. [W:] H. Sęk (red.), Psychologia kliniczna (t. 1, s. 269-298). Warszawa: Wydawnictwo Naukowe PWN.

DeRenard L. A., Kline L. M. (1990). Alienation and the game dungeons and dragons. Psychological Reports, 66, June, 1219-1222.

Emunah R. (1994). Acting for Real. Drama Therapy, Process, Technique, and Performance. New York, London: Brunner-Routledge.

Goleman D. (1997). Inteligencja emocjonalna, tłum. A. Jankowski. Poznań: Wydawnictwo Media Rodzina. 
Hsu S. H., Kao C.-H., Wu M.-C. (2007). Factors Influencing Player Preferences for Heroic Roles in Role-Playing Games. Cyberpsychology and Behavior, 10 (2), 293-295.

Hughes J. (1988). Therapy is Fantasy: Roleplaying, Healing and the Construction of Symbolic Order. Paper presented in Anthropology IV Honours, Medical Anthropology Seminar, Dr. Margo Lyon, Dept. of Prehistory and Anthropology, Australian National University, http:// www.rpgstudies.net/hughes/therapy_is_fantasy.html [dostęp: 12.01.2015].

Landy R. (2009). Role theory and role method of dramatherapy. [W:] D. R. Johnson, R. Emunah (red.), Current Approaches in Dramatherapy (s. 65-88). Springfield, Illinois: Charles C. Thomas Publisher.

Mellibruda J. (2003). Ja - ty - my: psychologiczne możliwości ulepszania kontaktów międzyludzkich. Warszawa: Instytut Psychologii Zdrowia PTP.

Paluchowski W. J., Hornowska E. (2003). Problemy teoretyczne diagnozy psychologicznej. [W:] J. Strelau. (red.), Psychologia. Podręcznik akademicki. Podstawy psychologii (t. 1, s. 509519). Gdańsk: Gdańskie Wydawnictwo Psychologiczne.

Panak P., Drzewiecka O. (2005). Gry fabularne. Mit a rzeczywistość: potencjalne wykorzystanie technik narracyjnych gier fabularnych $w$ dydaktyce, pedagogice i terapii. „Szkoła Specjalna”, 66(1), 19-29.

Prajzner K. (2009). Tekst jako świat i gra. Modele narracyjności w kulturze współczesnej. Łódź: Wydawnictwo Uniwersytetu Łódzkiego.

Rein-Hagen M., Davis G., Dowd T., Stevens L., Wieck S. (2002). Wampir: Maskarada. Narracyjna Gra Grozy. Warszawa: Wydawnictwo ISA Sp. z o.o.

Rembowski J. (1986). Metoda projekcyjna w psychologii dzieci i młodzieży. Warszawa: Państwowe Wydawnictwo Naukowe.

Russoniello C., O'Brien K., Parks J. M. (2009). The effectiveness of casual video games in improving mood and decreasing stress. Journal of Cyber Therapy and Rehabilitation, 2 (1), 53-66.

Simon A. (1987). Emotional Stability Pertaining to the Game of Dungeons and Dragons. Psychology in the Schools, 24, 329-332.

Simon A. (1998). Emotional stability pertaining to the game Vampire: The Masquerade. Psychological Reports, 83 (2), 732-734.

Stasiakiewicz M. (2003). Testy projekcyjne. [W:] J. Strelau (red.), Psychologia. Podręcznik akademicki. Podstawy psychologii (t. 1, s. 491-503). Gdańsk: Gdańskie Wydawnictwo Psychologiczne.

Szeja J. Z. (2004). Gry fabularne. Nowe zjawisko kultury wspótczesnej. Kraków: Wydawnictwo Rabid.

Szymanik A., Kostrzewski M. (2012). Gry narracyjne jako metoda i narzędzie w nauce. Forum Dydaktyczne. Przeszłość - Teraźniejszość - Przyszłość, 9-10, 166-178.

Szymanik A., Mączyńska J. (2010). Wykorzystanie gry narracyjnej w diagnozie i terapii - możliwości i ograniczenia. Wystapienie na konferencji „Homo narrator. Badanie opowieści o doświadczeniu”. Spała, 3-5 listopada $2010 \mathrm{r}$.

Taylor S. E., Klein L. C., Lewis B. P., Gruenewald T. L., Gurung R. A. R., Updegraff J. A. (2000). Biobehavioral responses to stress in females: Tend-and-befriend, not fight-or-flight. Psychological Review, 107 (3), 411-429.

Thayer R. E., Newman J. R., McClain T. M. (1994). Self-regulation of mood: strategies for changing a bad mood, raising energy, and reducing tension. Journal of Personality and Social Psychology, 67 (5), 910-925. 
AnNa SZymaniK-KostrzewsKa

\title{
THE NARRATIVE GAMES IN PSYCHOLOGICAL DIAGNOSIS AND THERAPY. POSSIBILITIES AND LIMITATIONS IN THEIR APPLICATION
}

\begin{abstract}
The article concerns possible use of narrative games in psychology. Narrative games are recognized as projective games, which allow to reach some hidden needs and motives of players by means of using the game world - a set of symbols which have a personal meaning for the players. Diagnosis of the players is possible due to analyzing characteristics and behavior of the characters they create. Therapy with the use of narrative games allows to support treatment of some mental disorders (such as phobia or depression), helps to develop social skills, to cope with unpleasant emotions and to create ways of thinking. Contraindications against the use of narrative games in diagnosis and therapy include psychotic and personality disorders, intellectual deficits, and inability to separate the Self from the Self-of-Character.
\end{abstract}

Keywords: narrative games, psychological diagnosis, psychological therapy. 